\author{
®Ю. А. Батман ${ }^{1}$, Л. В. Натрус ${ }^{2}$, О. Р. Есакова ${ }^{3}$ \\ 'ГУ «Институт педиатрии, акушерства и гинекологии НАМНУкраины»» \\ ${ }^{2}$ Научно-исследовательский институт экспериментальной и клинической медицинь \\ Национального медицинского университета имени А. А. Богомольиза, Киев \\ ${ }^{3}$ Донецикий национальный медицинский университет имени М. Горького

\section{КЛИНИКО-ДИАГНОСТИЧЕСКИЕ МАРКЕРЫ РАННЕЙ ДИАГНОСТИКИ ВНУТРИУТРОБНЫХ ИНФЕКЦИЙ У НЕДОНОШЕННЫХ НОВОРОЖДЕННЫХ}

КЛИНИКО-ДИАГНОСТИЧЕСКИЕ МАРКЕРЫ РАННЕЙ ДИАГНОСТИКИ ВНУТРИУТРОБНЫХ ИНФЕКЦИЙ У НЕДОНОШЕННЫХ НОВОРОЖДЕННЫХ. ВНутриутробные инфекции (ВУИ) на современном этапе являются одной из важнейших проблем акушерства и перинатологии. Вопросы диагностики, лечения и профилактики ВУИ до настоящего времени не изучены в достаточной мере и по-прежнему остаются той частью современной перинатологии, которая требует всестороннего изучения. Поэтому целью нашего исследования было изучить клинико-лабораторные маркеры ранней диагностики внутриутробных инфекций у недоношенных детей. В процессе исследования было обследовано 43 недоношенных новорожденных ребенка в возрасте 1-х суток и повторно на 15-е сутки, проведен ретроспективный анализ соматического и акушерско-гинекологического анамнеза матерей этих новорожденных. Проведенные исследования свидетельствуют о роли материнской инфекции не только в формировании осложненной беременности, преждевременных родов, в развитии внутриутробного инфицирования, задержки внутриутробного развития плода, но и в снижении адаптивных возможностей новорожденного в раннем неонатальном периоде. С целью повышения эффективности ранней диагностики ВУИ недоношенным детям, родившимся от матерей с факторами риска, рекомендуется взятие пуповинной крови на момент рождения и венозной крови на момент рождения и повторно на 15-е сутки на предмет выявления этиологии ВУИ методом полимеразной цепной реакции.

КЛІНІКО-ДІАГНОСТИЧНІ МАРКЕРИ РАННЬОЇ ДІАГНОСТИКИ ВНУТРІШНЬОУТРОБНИХ ІНФЕКЦІЙ У НЕДОНОШЕНИХ НОВОНАРОДЖЕНИХ. Внутрішньоутробні інфекції (ВУІ) на сучасному етапі $€$ однією з найважливіших проблем акушерства та перинатології. Питання діагностики, лікування та профілактики ВУІ досі не вивчені достатньою мірою та, як і раніше, залишаються тією частиною сучасної перинатології, яка потребує всебічного вивчення. Тому метою нашого дослідження було вивчити клініко-лабораторні маркери ранньої діагностики внутрішньоутробних інфекцій у недоношених дітей. У процесі дослідження було обстежено 43 недоношених новонароджених дитини віком 1-х діб і повторно на 15-ту добу, проведено ретроспективний аналіз соматичного та акушерсько-гінекологічного анамнезу матерів цих новонароджених. Проведені дослідження свідчать про роль материнської інфекції не тільки у формуванні ускладненої вагітності, передчасних пологів, у розвитку внутрішньоутробного інфікування, затримки внутрішньоутробного розвитку плода, але і в зниженні адаптивних можливостей новонародженого в ранньому неонатальному періоді. 3 метою підвищення ефективності ранньої діагностики ВУІ недоношеним дітям, які народилися від матерів з факторами ризику, рекомендується взяття пуповинної крові на момент народження та венозної крові на момент народження і повторно на 15-ту добу на предмет виявлення етіології ВУІ методом полімеразної ланцюгової реакції.

CLINICAL AND DIAGNOSTIC MARKERS OF EARLY DIAGNOSIS OF PRENATAL INFECTIONS IN PREMATURE NEWBORNS. Prenatal infection at the present stage are one of the major problems of obstetrics and perinatology. Issues of diagnosis, treatment and prevention of prenatal infections to date have not been studied sufficiently, and still remain part of the modern perinatology, which requires in-depth study. Therefore, the aim of our study was to investigate clinical and laboratory markers for early diagnosis of prenatal infection in premature newborns. In the course of the study were examined 43 premature newborn child at the age of 1 day and again on the 15th day, conducted a retrospective analysis of medical and obstetric history of the mothers of these newborns. Studies have shown a role of maternal infection not only in the formation of a complicated pregnancy, premature birth, and in the development of prenatal infection, intrauterine development of the fetus, but also in reducing the adaptive capacity of the newborn in the early neonatal period. To improve the effectiveness of early diagnosis of prenatal infection in premature newborns born to mothers with risk factors, it is recommended to take cord blood at birth and venous blood at birth and again at 15th day to identify the etiology of prenatal infections by polymerase chain reaction.

Ключевые слова: внутриутробные инфекции, недоношенные новорожденные, герпесвирусные инфекции. Ключові слова: внутрішньоутробні інфекції, недоношені новонароджені, герпесвірусні інфекції.

Key words: prenatal infection, premature newborns, herpes virus infection.

ВВЕДЕНИЕ. Внутриутробные инфекции (ВУИ) группа инфекционно-воспалительных заболеваний плода и новорожденного, вызванных различными возбудителями, но характеризующихся общими эпи- демиологическими закономерностями и нередко имеющих сходные клинические проявления [1].

У плода и новорожденного наряду с острым процессом может наблюдаться длительная персистен- 


\section{Педіатрія}

ция возбудителя с формированием латентного или медленно текущего хронического инфекционного процесса. В связи с этим, ВУИ имеют большое значение в патогенезе многих патологических состояний, формирующихся в последующие годы жизни.

ВУИ играют ключевую роль в структуре перинатальной, младенческой заболеваемости и смертности, их частота не имеет тенденции к снижению [2].

В последние годы на фоне повсеместного роста иммунодефицитных состояний характер глобальной медико-социальной проблемы приобрели герпесвирусные инфекции (ГВИ) вследствие их широкого распространения и крайне неблагоприятного влияния на уровень общего и репродуктивного здоровья населения [6].

Известно, что представителям семейства Herpesviridae принадлежит преобладающая роль в этиологии спонтанных абортов и преждевременных родов, в нарушении эмбрио- и органогенеза, врожденной патологии новорожденных. Вирус Эпштейна-Барр (ВЭБ) наравне с вирусами простого герпеса (ВПГ) 1 и 2 типов и цитомегаловирусом (ЦМВ) входит в число возбудителей TORCH-инфекций. На основании экспериментальных данных было установлено, что поражение плаценты и трансплацентарное заражение эмбриона и плода могут происходить при любом сроке беременности [7].

Высокий метаболизм клеток плода является довольно благоприятной почвой для активного размножения всех вирусов, но ЦМВ обладает значительной тропностью к эмбриональной ткани. Местом наибольшей репликации ЦМВ в организме человека являются слюнные железы. Наружная оболочка ВПГ имеет специфические рецепторы, обеспечивающие способность присоединения к клеткам слизистых оболочек. Репликация ВЭБ, как правило, происходит в лимфоузлах носоглотки, и ангина является одним из типичных признаков заболевания.

Достоверных данных об истинной распространенности ВУИ нет, однако, согласно данным ряда исследователей, инфекционные заболевания выявляют у 50-60 \% доношенных и 70 \% недоношенных новорожденных. Внутриутробные вирусные инфекции могут привести к антенатальной гибели плода, самопроизвольному выкидышу, перинатальной смертности и невынашиванию беременности [3, 5].

Одним из важных вопросов сегодня остается рациональное и эффективное проведение лабораторного исследования на ВУИ у новорожденных. В литературе встречаются разноречивые сведения относительно частоты выявления у недоношенных новорожденных возбудителя инфекции, даже при наличии ясной клинической картины. Так же трудно выделить наиболее информативную биологическую среду для идентификации возбудителя.

Метод ПЦР-диагностики признан «золотым стандартом» выявления вирусного носительства, и при чувствительности $95 \%$ его точность сомнений не вызывает. Однако рекомендации ряда авторов определять все виды семейства Herpesviridae и во всех биологических средах (кровь, моча, пуповинная кровь, буккальный эпителий, ликвор) не могут быть восприняты как руководство к действию, как нерациональный и чрезмерно затратный подход. Поэтому одной из наших задач являлось выявить наиболее информативную среду для обнаружения возбудителя.

Инфицирование внутриутробно может вызывать разные по степени органные или функциональные изменения практически во всех органах и системах ребенка, способствовать формированию хронических рецидивирующих инфекционно-воспалительных процессов. Учитывая незрелость тканей плода и продолжение тканевой дифференцировки, мы сочли целесообразным повторить ПЦР-анализ через 15 дней после рождения.

Целью нашего исследования было изучить клинико-лабораторные маркеры ранней диагностики внутриутробных инфекций у недоношенных детей.

МАТЕРИАЛЫ И МЕТОДЫ. В процессе исследования было обследовано 43 недоношенных новорожденных ребенка в возрасте 1-х суток и повторно на 15-е сутки, находившихся в неонатальных отделениях Донецкого регионального центра охраны материнства и детства. Проведен ретроспективный анализ соматического и акушерско-гинекологического анамнеза матерей этих новорожденных.

Все исследуемые были условно разделены на 2 группы: основную и группу контроля. В свою очередь, основная группа была разделена на 2 подгруппы: 1-ю подгруппу составили 20 недоношенных с признаками инфекции и с отягощенным акушерско-гинекологическим анамнезом матери, ПЦР «положительный», во 2-ю подгруппу вошли 12 недоношенных с признаками инфекции, с отягощенным акушерско-гинекологическим анамнезом матери, ПЦР «отрицательный», группу контроля составили 11 недоношенных без клинических признаков инфекции, ПЦР «отрицательный».

Отбор больных осуществлялся только в соответствии с установленными критериями включения и исключения. Критериями включения были срок гестации 36 недель и менее, масса тела менее 2500,0 г, критериями исключения - несоответствие хотя бы одному критерию включения плюс пороки развития, не совместимые с жизнью, врожденные пороки сердца.

Методология нашего исследования заключалась в определении ВПГ 1 и 2 типов, ВЭБ и ЦМВ методом полимеразной цепной реакции (ПЦР): в пуповинной крови на момент рождения, в венозной крови, буккальном соскобе и моче на момент рождения и на 15-е сутки жизни. Забор биоматериала для исследования производился в родильном зале или операционной и в неонатальных отделениях. Материал транспортировался в течение первых 4-х часов при температуре от 0 до $+4{ }^{\circ} \mathrm{C}$ в лабораторию.

Исследования методом ПЦР выполнялись в отделении лабораторных исследований Университетской клиники ДонНМУ имени М. Горького на амплификаторе HYBAID (США). Использовались наборы реагентов фирмы «Литех» (Россия) с флюоресцентной меткой one-step для качественного анализа. Учет результатов производился системой «Джин» с помощью специальной компьютерной программы. 
РЕЗУЛЬТАТЫ ИССЛЕДОВАНИЯ И ИХ ОБСУЖДЕНИЕ. Мы выявили, что наиболее частым возбудителем ВУИ является ЦМВ, который был обнаружен у $80 \%$ недоношенных новорожденных. В наших предыдущих исследованиях по изучению причин бронхолегочной дисплазии (БЛД) у недоношенных новорожденных массой 1500 г и менее также определяли ЦМВ как ведущий возбудитель. В группе недоношенных новорожденных, получавших ИВЛ, каждый 4 ребенок имел ЦМВ, т.е. распространенность составила $25 \%$. Мы считаем, что ЦМВ играет значительную роль в развитии незрелости респираторного эпителия, подавлении активности сурфактантной системы и развитии БЛД. Как мы уже отмечали, степень органического поражения плода зависит от интенсивности размножения вируса и от периода гестации, в который происходит развитие инфекции. Интенсивное деление ЦМВ в системе мать-плод, если и не было первопричиной респираторной незрелости, то значительно ее усугубило [4].

Анализ биологических сред, используемых для выявления ЦМВ, показал, что наиболее информативным материалом для обнаружения вируса в организме новорожденного послужила венозная кровь - в ней вирус обнаруживали в $80 \%$ случаев, в пуповинной крови - $65 \%$, буккальном соскобе - $55 \%$, моче - $35 \%$.

Также в $35 \%$ случаев в венозной крови был выделен ВПГ 1 типа, а в 25 \% были идентифицированы такие возбудители, как уреаплазма и микоплазма.

ВПг 2 типа и ВЭБ не были выделены ни в одном случае.

При повторном взятии материала у исследуемых новорожденных в 6 случаях результат ПЦР на ЦМВ выявлен положительным (при первичном обследовании у данных новорожденных ПЦР был отрицательным): в буккальном соскобе - у 2-х новорожденных, в венозной крови - у 3-х новорожденных, в моче у 1-го новорожденного.

То есть, практически у трети новорожденных носительство вируса было установлено позже, через 2 недели, а не сразу после рождения. Вероятность заражения ЦМВ во время пребывания в отделении мы отрицаем, поэтому можно думать о том, что вирус попал в организм плода внутриутробным путем, однако сразу после рождения выявить его не удалось.

То есть, даже высокочувствительный метод ПЦРамплификации в ряде случаев не позволяет праймерам обнаружить участок генома вируса. Учитывая незрелость клеточного состава у недоношенных новорожденных и, вероятно, продолжающиеся митозы, мы предполагаем, что существует некий физиологический механизм, маскирующий нуклеиновый состав ДНК плода и не позволяющий идентифицировать участок генома вируса в смеси с ДНК хозяина. Безусловно, наше предположение требует дальнейших исследований, однако уже сегодня мы можем утверждать, что с целью повышения эффективности ранней диагностики ВУИ недоношенным детям, родившимся от матерей с факторами риска, рекомендуется на предмет выявления этиологии ВУИ методом ПЦР взятие венозной крови через некоторое время после рождения.
Течение беременности, исход родов, состояние новорожденных во многом зависят не только от характера инфекционного процесса во время беременности, но и от ряда социальных факторов, среди которых существенное значение имеют возрастные грани.

Подавляющее большинство всех наблюдаемых женщин было в возрасте старше 30 лет. Влияние соматических и инфекционных заболеваний матери, акушерской патологии, осложненного течения беременности и родов на развитие плода и новорожденного имеет существенное значение и во многом определяет состояние его иммунной системы, течение адаптационного периода, заболеваемость и смертность. Это обусловило необходимость проведения анализа частоты встречаемости отдельных факторов риска.

Ретроспективный анализ данных акушерско-гинекологического анамнеза матерей, в том числе соматического здоровья и течения настоящей беременности, показал, что в основной группе все женщины имели очаги хронической инфекции (кольпит, пиелонефрит, гастрит, тонзиллит и прочее), перенесли ОРВИ (84,3\%), раннее излитие околоплодных вод (более 12 часов) встречалось в 75 \% случаев, положительные результаты TORCH-исследований были выявлены в $56,2 \%$.

В группе контроля на первый план вышли преждевременная отслойка нормально расположенной плаценты - 63,6 \%, преэклампсия - 45,5 \%, медицинские аборты - 36,3 \%.

Существенное значение имел факт наличия во всех группах фетоплацентарной недостаточности (ФПН) (в основной группе - 46,8 \%, в группе контроля - 72,7\%). Острая и хроническая ФПН приводила к нарушению микроциркуляции в плаценте, изменению ее функций с последующей дезадаптацией новорожденного в раннем неонатальном периоде. В результате среди общего числа наблюдаемых новорожденных 63,2 \% родились с признаками хронической внутриутробной гипоксии плода.

Среди новорожденных детей основной группы в асфиксии средней тяжести родились $75 \%$, в тяжелой асфиксии - $25 \%$, в группе сравнения - 64 и $36.3 \%$ соответственно. Почти в $80 \%$ случаев в обоих группах проводилась сурфактантная терапия.

Среди основных клинических синдромов после родов и в первые часы и дни после рождения у наблюдаемых новорожденных преобладали неврологические расстройства, синдром дыхательных расстройств (в основной группе - $84,3 \%$, в группе сравнения - $80,1 \%)$, желтуха. Желтушный синдром отмечался у значительной части новорожденных (в основной группе - 90,6 \%, в группе сравнения $56.4 \%$ ). Иктеричность кожных покровов, видимых слизистых оболочек и склер появлялась на 1-й и 2-й дни жизни и длительно сохранялась. Более длительный желтушный период имели новорожденные основной группы - 21 день, чем новорожденные группы сравнения - 16 дней.

Дыхательная недостаточность сохранялась длительное время, и развивалась пневмония. 


\section{Педіатрія}

Характерным являлось развитие отечного синдрома (в основной группе - 56,2 \%, в группе сравнения - 47,4 \%). У новорожденных с выявленными сочетанными ВУИ отмечалась гепатоспленомегалия.

Нарушения терморегуляции, микроциркуляции, акроцианоз также чаще встречались в основной группе, чем в группе сравнения. Восстановление массы тела в более длительные сроки, позже двухнедельного возраста, также превалировало у детей основной группы (34,5 \%), чем у новорожденных группы сравнения $(29,7 \%)$.

ВывОДЫ. 1. Проведенные исследования свидетельствуют о роли материнской инфекции не только в формировании осложненной беременности, преждевременных родов, в развитии внутриутробного инфицирования, задержки внутриутробного развития плода, но и в снижении адаптивных возмож- ностей новорожденного в раннем неонатальном периоде.

2. Выявлено, что у новорожденных детей с ВУИ в раннем неонатальном периоде отмечаются клинические проявления дезадаптации: синдром дыхательных расстройств, отечный синдром, снижение церебральной и двигательной активности, нарушения терморегуляции, восстановление массы тела позже двухнедельного возраста, частота которых достоверно выше, чем в группе сравнения.

ПЕРСПЕКТИВЫ ДАЛЬНЕЙШИХ ИССЛЕДОВАНИЙ. С целью повышения эффективности ранней диагностики ВУИ недоношенным детям, родившимся от матерей с факторами риска, рекомендуется взятие пуповинной крови на момент рождения и венозной крови на момент рождения и повторно на 15-е сутки на предмет выявления этиологии ВУИ методом ПЦР.

\section{СПИСОК ЛИТЕРАТУРЫ}

1. Неонатология : национальное руководство / под ред. Н. Н. Володина. - М. : ГОЭТАР-Медиа, 2008. - 566 с.

2. Кулаков В. И. Новорожденные высокого риска, новые диагностические и лечебные технологии / В. И. Кулаков, Ю. И. Барашнев. - М. : ГОЭТАР-Медиа, 2007. - 524 c.

3. TORCH-инфекции в акушерстве и неонатологии / под ред. Т. К. Знаменской. - 2008. - С. 15.

4. Роль герпесвирусных инфекций в незрелости респираторного эпителия недоношенных детей / Ю. А. Батман, Л. В. Натрус, В. В. Павлюченко [и др.] // Університетська клініка. - 2012. - Т. 8, № 2. - С. 213 217.
5. Редькин Ю. В. Оппортунистические инфекции: проблемы и перспективы / Ю. В. Редькин, О. А. Мирошника, В. В. Лобова. - Омск : ОГМА, 2002. - 100 с.

6. PCR-мониторинг основных TORCH-инфекций (токсоплазмоз, ЦМВ, ВПГ 1, 2, ВЭБ) в патологии новорожденных в Киеве / И. С. Марков, Е. Е. Шунько, Н. Т. Муравьева [и др.] // Репродуктивное здоровье женщины. - 2002. - № 2. - С. 122-129.

7. Охотникова И. М. Значение внутриутробной вирусной инфекции в органной патологии детей грудного возраста / И. М. Охотникова, В. А. Агейкин, Л. С. Лозовская // Мед. научный и учебно-методический журнал. - 2001. - № 5. - С. 81-87. 